\title{
Rancang Bangun Sistem Informasi Arsip Surat Menggunakan Metode Prototype
}

\author{
http://dx.doi.org/10.28932/jutisi.v7i2.3664 \\ Riwayat Artikel \\ Received: 7 Juni 2021 | Final Revision: 21 Juni 2021 | Accepted: 06 Juli 2021

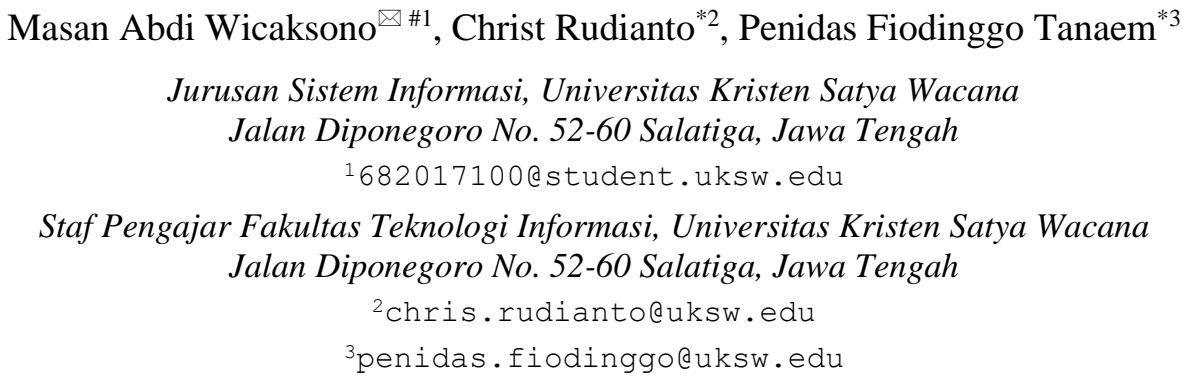

Abstract - Letters archiving is the process of receiving, collecting, maintaining letters in a structured manner by an agency, however, the process of filing letters at the Unit Pelaksana Teknis Daerah (UPTD) Satuan Pendidikan Non Formal (SPNF) Sanggar Kegiatan Belajar (SKB) Salatiga still has problems such as recording letter archive data that still uses a letter agenda book which sometimes occurs errors in recording, archival document storage which is physically stored on a mailing cabinet which is prone to being lost, scattered, or damaged and the large number of existing documents causes employees to need extra time and effort to look for them. With the Letter Archive Information System designed using the prototype method, it allows employees to take part in the design of this system by providing opinions and suggestions on system design so that the results will be more optimal, maximum and can be a solution to the problems that exist in the Unit Pelaksana Teknis Daerah (UPTD) Satuan Pendidikan Non Formal (SPNF) Sanggar Kegiatan Belajar (SKB) Salatiga.

Keywords— Archive; Information; Letter; Prototype; System.

\section{PENDAhuluan}

UPTD SPNF SKB Salatiga yang beralamat di JL. Soekarno Hatta Isep Isep, Argomulyo, Salatiga adalah unit pelaksana teknis daerah yang menjalankan kegiatan pendidikan non formal pada Kota Salatiga yang posisinya berada di bawah Dinas Pendidikan Kota Salatiga. UPTD SPNF SKB Salatiga menjalankan berbagai macam program pendidikan yang bersifat non formal diantaranya pendidikan anak usia dini, pendidikan kesetaraan, pelatihan keterampilan tertentu, dan program lainnya yang bertujuan untuk meningkatkan kecerdasan sumber daya manusia, memberikan pendidikan tentang kecakapan hidup dengan menggali potensi yang dimiliki oleh peserta didik di bidang non formal.

Pengelolaan arsip surat pada UPTD SPNF SKB Salatiga adalah salah satu kegiatan yang sering dilakukan, mulai dari penerimaan surat yang dilakukan oleh tata usaha, surat tersebut dicatat oleh sekretaris pada buku agenda surat, surat yang sudah dicatat ke dalam buku agenda surat disimpan pada rak lemari arsip secara fisik atau hardcopy. Manajemen arsip surat pada UPTD SPNF SKB Salatiga dinilai kurang efektif dan efisien karena bisa terjadi kemungkinan adanya kesalahan dalam pencatatan kedalam buku agenda surat, surat yang disimpan pada rak lemari arsip berisiko mengalami kerusakan, tercecer, dan rawan hilang [1], dengan banyaknya dokumen surat yang tersimpan pada rak lemari arsip menyebabkan para pegawai membutuhkan waktu dan tenaga ekstra dalam pencarian dokumen tersebut.

Berdasarkan permasalahan yang ada, dibutuhkan sistem informasi arsip surat berbasis website yang dapat untuk menyimpan dokumen arsip dalam bentuk softfile sehingga dokumen arsip terjaga dari kerusakan, tercecer, maupun hilang, keuntungan lain yang diperoleh adalah pencarian data dokumen arsip yang sebelumnya membutuhkan waktu dan tenaga ekstra sekarang dapat dilakukan dengan lebih cepat dan efisien. Sistem informasi arsip surat ini dibangun dengan metode pengembangan sistem prototype yang memudahkan klien dan pengembang dalam menjalankan proyek karena masingmasing pihak berperan aktif dan ikut serta dalam pengembangan sistem. 
Penggunaan metode prototype pada sistem informasi arsip surat ini diharapkan (1) dapat mempermudah pengembang dalam merancang sistem dengan adanya feedback dari pegawai UPTD SPNF SKB Salatiga berupa pendapat dan saran tentang perancangan sistem sehingga hasilnya akan lebih optimal dan mudah disesuaikan dengan kebutuhan dari klien, (2) dapat mengatasi permasalahan tentang pengarsipan surat di UPTD SPNF SKB Salatiga dan meningkatkan efisiensi dalam pekerjaan.

Penelitian yang dilakukan oleh Suryadi [2] menjelaskan tentang aktivitas pengarsipan surat di Kantor Desa Karangrau di antaranya pembuatan, pengumpulan, hingga pemeliharaan surat dilakukan dengan cara konvensional. Berkas arsip surat disimpan dalam bentuk fisik dan dicatat pada buku besar. Pada saat pencarian dokumen yang sudah lama tersimpan harus dicari satu-persatu sehingga menimbulkan kesulitan dalam pencarian dokumen karena menyita waktu yang cukup banyak. Penelitian ini menghasilkan sistem pengelolaan arsip surat berbasis website sebagai alat bantu pengelolaan arsip surat pada Kantor Desa Karangrau.

Penelitian oleh Prabowo, Kurniawan [3] memiliki tujuan untuk merancang aplikasi berbasis website dengan menggunakan bahasa pemrograman PHP dengan framework Laravel, basis data MySQL dan Metode Waterfall sebagai metode pengembangan sistem. Hasil rancang bangun penelitian ini adalah aplikasi Pengarsipan Surat dan Disposisi (APSD).

Penelitian dari Maulana, Kasmawi, Enda [4] yang dilakukan di SDN 04 Bengkalis merancang sebuah aplikasi untuk mencatat aktivitas yang dilakukan siswa pada saat di sekolah bersama dengan catatan yang ditujukan untuk orang tua di rumah. Penelitian ini membangun aplikasi buku penghubung berbasis android menggunakan metode prototype sebagai metode pengembangan sistem dengan membuat prototype awal aplikasi dan mendiskusikannya dengan pengguna aplikasi yaitu orang tua dan guru sampai terciptanya aplikasi yang sesuai harapan. Penelitian ini menghasilkan sebuah aplikasi Buku Penghubung berbasis Android yang memudahkan orang tua dan guru dalam penyampaian informasi.

Berdasarkan pada tiga penelitian terdahulu dapat disimpulkan bahwa pada penelitian yang dilakukan oleh Suryadi [2] memiliki kemiripan dengan penelitian ini yaitu permasalahan yang ada, yang membedakan penelitian ini adalah metode pengembangan yang digunakan yaitu metode prototype. Penelitian oleh Prabowo, Kurniawan [3] mempunyai persamaan dengan penelitian ini yaitu perancangan aplikasi dengan basis website dan menggunakan PHP dan MySQL untuk merancang aplikasi, perbedaan dari penelitian ini terletak pada penggunaan framework yaitu Codeigniter. Penelitian dari Maulana, Kasmawi, Enda [4] memiliki kesamaan dengan penelitian ini yaitu penggunaan metode prototype dalam pengembangan sistem, perbedaan yang ada yaitu pengembangan sistem pada penelitian ini menggunakan bahasa pemrograman PHP dengan basis data MySQL.

Surat merupakan alat komunikasi yang berisi pernyataan, tanggapan, laporan, perintah secara tertulis sesuai dengan apa yang ingin disampaikan oleh pembuat surat tersebut [5]. Surat merupakan percakapan tertulis antara suatu instansi ke instansi lainnya, pihak satu dengan pihak lain, atau seseorang dengan seseorang. Surat menjadi sarana untuk saling bertukar informasi antar pihak.

Arsip ialah rekaman aktivitas dalam bermacam wujud yang memiliki makna serta tujuan tersendiri sebagai bahan komunikasi dan informasi. Arsip dibuat, disimpan, dan dipelihara secara terstruktur oleh suatu instansi atau organisasi selama masih diperlukan. Arsip disimpan secara sistematis yang berguna ketika dokumen diperlukan kembali bisa ditemukan dengan cepat [6].

Sistem informasi adalah sebuah kerangka kerja untuk menghimpun data, mengolah data, menjabarkan data, dan memberikan output berupa informasi yang dikelola oleh sumber daya manusia dan teknologi informasi digunakan demi tercapainya tujuan suatu organisasi [7]. Sistem informasi merupakan gabungan terstruktur dari jaringan komunikasi, individu, perangkat keras, perangkat lunak, dan sekumpulan data yang dikumpulkan, diolah, dan disajikan dalam bentuk informasi ke sebuah organisasi [8].

PHP atau sering disebut Hypertext Preprocessor merupakan bahasa pemrograman open source yang berjalan pada sisi server yang dibuat untuk membangun sebuah website serta bisa ditampilkan pada suatu skrip HTML. PHP memproses informasi melalui sisi server, singkatnya, skrip PHP diterjemahkan oleh server dan sesudah itu hasil tersebut dikirim ke klien yang melakukan permintaan [9]. Bahasa pemrograman PHP mudah untuk dipelajari karena metode pemrogramannya mirip dengan bahasa pemrograman lainnya seperti Java, Python, C++, C, dan lainnya sehingga programmer dapat dengan mudah menggunakannya.

Codeigniter adalah framework dari bahasa pemrograman PHP untuk membangun sebuah sistem atau aplikasi berbasis website [10]. Codeigniter diciptakan untuk pengembang dengan menyediakan package yang mudah digunakan dan memiliki library dan helper yang dapat membuat website yang memiliki fitur yang lengkap. Codeigniter adalah framework berbasis MVC (Model, View, Controller) untuk pengembangan website.

MySQL merupakan suatu database management system (DBMS) yang berfungsi sebagai sistem basis data relasional (RDBMS). Tidak hanya itu, MySQL adalah server basis data yang bersifat open source dan server database MySQL mempunyai performa yang baik, memiliki fitur keamanan yang bagus, serta mudah untuk digunakan. Dikarenakan MySQL 
sifatnya open source dan mudah digunakan sehingga cocok digunakan untuk mempresentasikan proses simulasi database [11].

\section{MEtOde PENELITIAN}

Penelitian ini menggunakan metode penelitian deskriptif, sebab penelitian ini mempunyai tujuan menjabarkan kasus yang terjadi saat ini dengan mengumpulkan data saat melakukan penelitian. Metode penelitian deskriptif merupakan metode yang mempelajari individu, entitas, kelas, keadaan, sistem pemikiran, maupun kejadian pada saat ini. Penelitian deskriptif bertujuan untuk membuat deskripsi secara terstruktur, relevansi dari fakta yang didapat, perilaku serta hubungan antar studi kasus yang diteliti.

\section{A. Metode Pengembangan Perangkat Lunak}

Metode pengembangan perangkat lunak yang digunakan adalah metode prototype. Metode ini sesuai untuk sistem yang memerlukan banyak perubahan pada fitur-fiturnya. Metode prototype diawali dengan mengumpulkan kebutuhan klien dalam penelitian ini yaitu pegawai UPTD SPNF SKB Salatiga. Setelah kebutuhan klien terkumpul, pengembang membuat rancangan awal dari aplikasi atau prototype dari aplikasi yang berikutnya hendak dievaluasi kembali sampai menjadi aplikasi yang siap untuk dipakai [12].

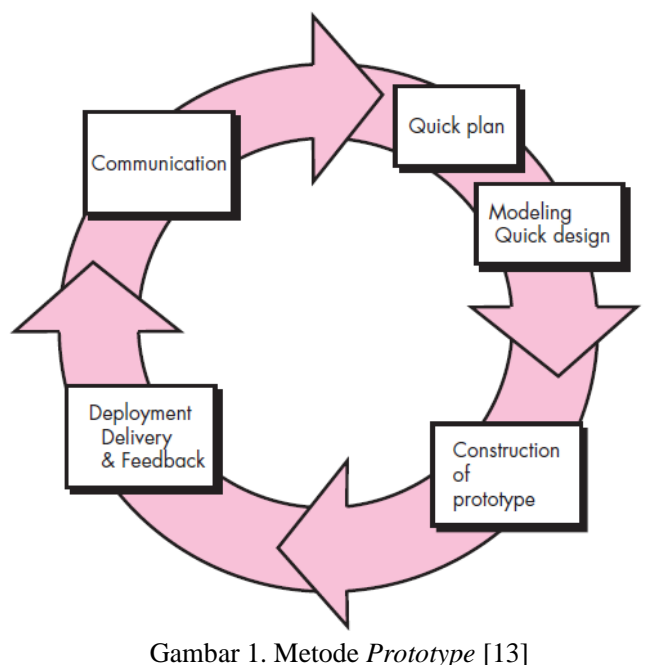

Gambar 1 adalah tahapan dari metode prototype yang terdiri atas 4 tahapan, di antaranya:

\section{A. Communication}

Communication adalah tahap bertemunya pengembang dan klien mendiskusikan tentang perangkat lunak yang akan dibuat kelak. Pada tahap ini pengembang berkoordinasi dengan pihak UPTD SPNF SKB Salatiga untuk mengumpulkan informasi tentang proses pengarsipan surat pada UPTD SPNF SKB Salatiga dan informasi yang terkait dengan pengarsipan surat. Dari hasil diskusi dengan pihak UPTD SPNF SKB Salatiga menghasilkan alur pengarsipan surat, tata cara pencatatan surat ke dalam buku agenda, proses disposisi surat, pembuatan laporan surat, pemantauan surat, dan pembuatan lembar disposisi. Sistem pengarsipan surat yang berjalan pada UPTD SPNF SKB Salatiga di antaranya:

1) Pencatatan Surat Masuk: Staf tata usaha menerima surat dari instansi lain melalui kurir, setelah itu staf tata usaha menyalin surat serta disimpan ke lemari arsip surat, melengkapi data surat masuk tersebut ke dalam buku agenda surat masuk dan diberikan kepada sekretaris untuk keperluan pemantauan surat. Selanjutnya surat masuk ditujukan kepada Kepala UPTD SPNF SKB Salatiga dan membuat disposisi kepada pihak tertuju, setelah disposisi diterima oleh pihak yang tertuju lalu memperbaharui tindakan disposisi.

2) Proses Surat Keluar: Setelah draf surat keluar dibuat kemudian diserahkan kepada Kepala UPTD SPNF SKB Salatiga untuk permintaan persetujuan surat keluar. Setelah disetujui, surat keluar tersebut diserahkan kepada staf tata usaha untuk disalin, dicatat dalam buku agenda surat keluar, disimpan ke lemari arsip surat, dan surat keluar siap dikirim.

Penyimpanan arsip surat secara fisik berisiko mengalami kerusakan atau tercecer seiring berjalannya waktu, jika pegawai UPTD SPNF SKB Salatiga membutuhkan dokumen lama yang disimpan di lemari arsip, terkadang staf tata usaha 
kesulitan dalam mencari dokumen yang terdahulu. Oleh karena itu analisa terhadap sistem yang berjalan diperlukan yang dijelaskan pada Tabel 1.

TABEL 1

ANALISA SISTEM YANG BERJALAN

\begin{tabular}{lll}
\hline No. & \multicolumn{1}{c}{ Kasus } & \multicolumn{1}{c}{ Solusi } \\
\hline $\mathbf{1}$ & $\begin{array}{l}\text { Pendataan surat masuk dan surat keluar dilaksanakan } \\
\text { dengan cara konvensional melalui penulisan pada buku } \\
\text { agenda, hal tersebut memungkinkan terjadinya kesalahan } \\
\text { pada pencatatan buku agenda. }\end{array}$ & $\begin{array}{l}\text { Merancang sebuah sistem informasi arsip surat berbasis website } \\
\text { yang memungkinkan untuk melakukan input buku agenda secara } \\
\text { terkomputerisasi dan meminimalisir timbulnya kekeliruan pada } \\
\text { penginputan data. }\end{array}$ \\
\hline $\mathbf{2}$ & $\begin{array}{l}\text { Surat masuk dan surat keluar disimpan di lemari arsip surat } \\
\text { secara fisik (hardcopy) yang berisiko surat tercecer dan } \\
\text { mengalami kerusakan seiring berjalannya waktu. }\end{array}$ & $\begin{array}{l}\text { Pada sistem informasi arsip surat yang akan dibuat, terdapat fitur } \\
\text { untuk upload file yang memungkinkan dokumen surat untuk } \\
\text { disimpan secara softcopy yang diharapkan dapat menghindari } \\
\text { kerusakan dan tercecernya surat. }\end{array}$ \\
\hline $\mathbf{3}$ & $\begin{array}{l}\text { Ketika pegawai membutuhkan dokumen lama yang } \\
\text { tersimpan pada lemari arsip surat, staf tata usaha mengalami } \\
\text { kesulitan dalam pencarian dokumen terdahulu tersebut. }\end{array}$ & $\begin{array}{l}\text { Membuat sebuah fungsi pencarian surat secara terkomputerisasi } \\
\text { yang dapat memudahkan staf tata usaha dalam mencari dokumen } \\
\text { terdahulu. }\end{array}$ \\
\hline
\end{tabular}

\section{B. Quick Plan \& Modelling Quick Design}

Setelah tahap communication, pengembang mengetahui tata cara sistem pengarsipan surat secara umum. Pengembang melakukan perancangan sistem secara cepat berdasarkan informasi yang telah diterima oleh pengembang. Use Case Diagram adalah diagram yang berguna untuk menggambarkan perilaku dari aktor pada sistem yang akan dirancang. Use Case Diagram menjelaskan sebuah relasi antara aktor dan sistem yang hendak dirancang. Use Case Diagram berguna untuk menjelaskan fungsi-fungsi dari sistem dan akses apa saja yang diberikan oleh aktor untuk memakai fungsi-fungsi tersebut. Tahap ini diawali dengan perancangan use case diagram.

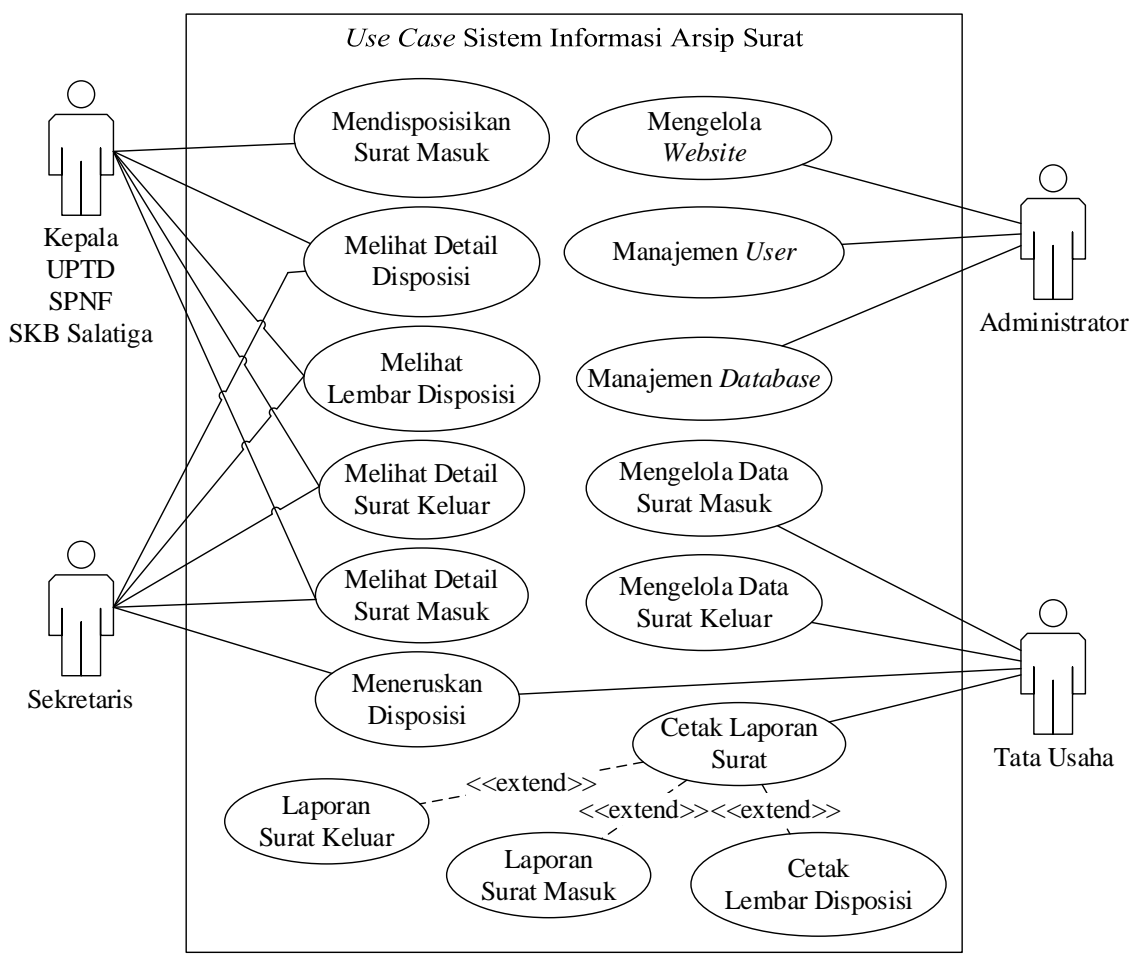

Gambar 2. Use Case Diagram Sistem Informasi Arsip Surat 
Gambar 2 adalah diagram yang menjelaskan tentang relasi sistem dan apa saja yang bisa dilakukan oleh aktor Kepala UPTD SPNF SKB Salatiga, Sekretaris, Administrator, dan Tata Usaha. Kepala UPTD SPNF SKB Salatiga dapat melakukan pembuatan disposisi surat masuk, melihat detail disposisi surat masuk, melihat lembar disposisi, melihat detail surat masuk, dan melihat detail surat keluar. Sekretaris mempunyai tugas untuk melakukan tracking atau pemantauan surat sehingga sekretaris dapat melihat lembar disposisi, melihat detail disposisi, melihat detail surat masuk, melihat detail surat keluar, dan meneruskan disposisi. Administrator berhak untuk mengelola website, manajemen user, dan manajemen database yaitu backup dan restore database. Tata Usaha dapat mengelola data surat masuk, mengelola data surat keluar, meneruskan disposisi, mencetak laporan surat yang terdiri dari cetak laporan surat masuk, cetak laporan surat keluar, dan cetak lembar disposisi.

Activity Diagram adalah workflow dalam berjalannya suatu sistem. Activity Diagram serta digunakan untuk mendeskripsikan atau mengumpulkan alur tampilan dari sistem. Activity Diagram mempunyai komponen dengan wujud spesifik yang dihubungkan dengan tanda panah. Tanda panah menjelaskan aliran kerja secara urut dari atas sampai akhir aktivitas. Setelah melakukan pembuatan use case diagram, pengembang membuat activity diagram untuk pencatatan surat masuk pada UPTD SPNF SKB Salatiga.

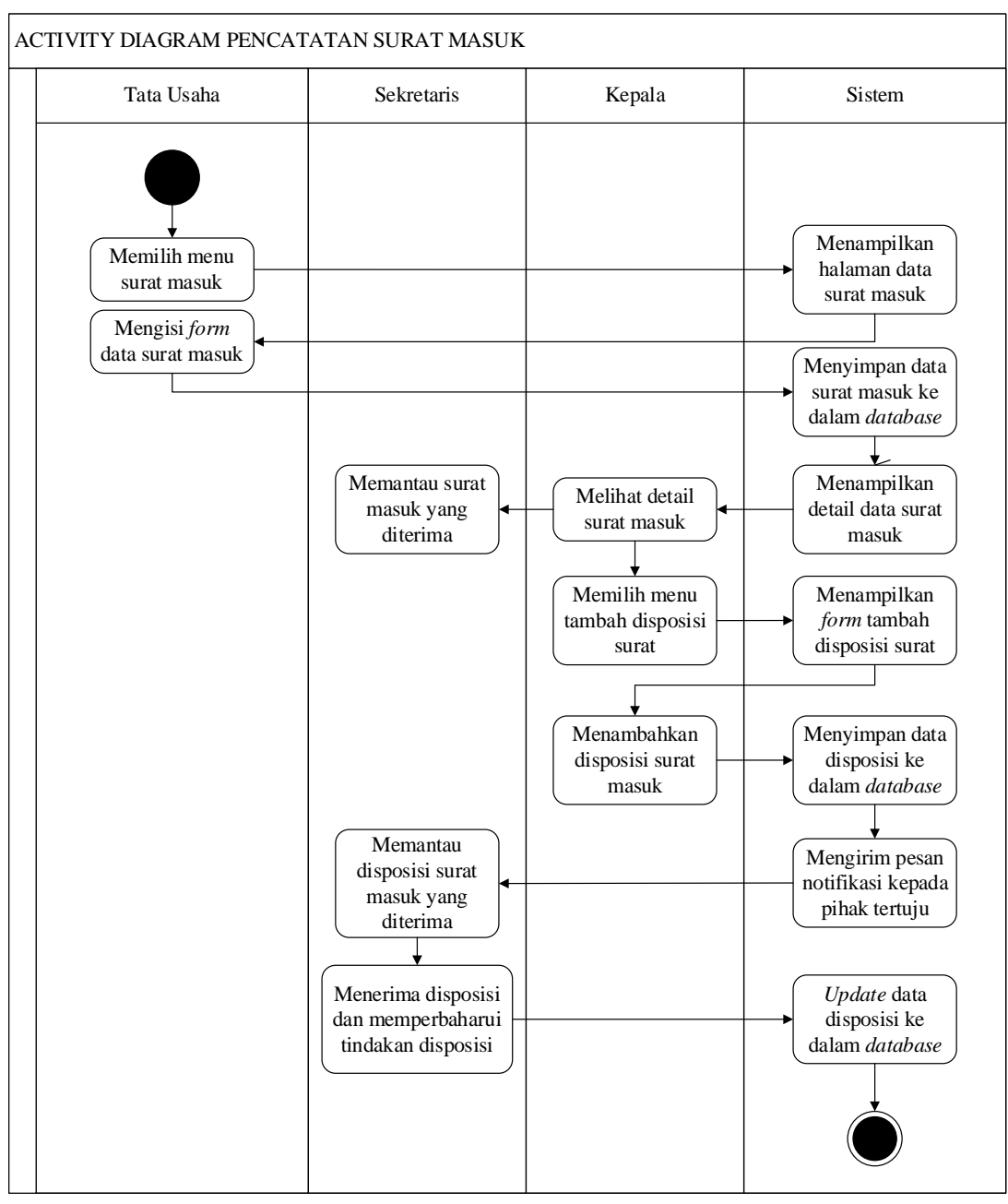

Gambar 3. Activity Diagram Pencatatan Surat Masuk

Gambar 3 merupakan activity diagram pencatatan surat masuk pada sistem informasi arsip surat yang dilakukan oleh aktor Tata Usaha, Sekretaris, dan Kepala UPTD SPNF SKB Salatiga. Aktivitas diawali dengan aktor Tata Usaha yang mengakses menu surat masuk, setelah itu melakukan input data surat masuk. Setelah data surat masuk tersimpan, sistem mengarahkan ke menu detail surat masuk, kemudian Kepala UPTD SPNF SKB Salatiga melihat detail surat masuk dan mendisposisikan surat masuk, pada tahap ini aktor Sekretaris memantau surat masuk yang diterima oleh Kepala UPTD 
SPNF SKB Salatiga. Setelah data disposisi surat masuk tersimpan, sistem akan mengirimkan notifikasi kepada pihak yang dituju sesuai dengan isi disposisi surat masuk. Setelah itu, pihak yang tertuju menerima disposisi dan melanjutkan proses pencatatan surat masuk dengan memperbaharui tindakan disposisi, kemudian sistem melakukan update data disposisi surat masuk ke dalam database.

Setelah dibuatnya activity diagram pencatatan surat masuk, pengembang kemudian membuat activity diagram proses surat keluar yang diawali dari Tata Usaha mengakses menu surat keluar, kemudian melakukan input draf surat keluar, setelah itu draf surat keluar yang sifatnya sementara tersebut disimpan ke dalam database. Kepala UPTD SPNF SKB Salatiga mendapatkan notifikasi adanya draf surat keluar eksternal baru, Sekretaris memantau draf surat keluar eksternal yang baru dan memeriksa surat tersebut, apabila tidak setuju dengan draf surat keluar eksternal tersebut maka akan dikembalikan kepada Tata Usaha untuk dilakukan perbaikan terhadap draf surat keluar eksternal tersebut. Jika Kepala UPTD SPNF SKB Salatiga menyetujui draf surat keluar eksternal tersebut, akan menandatangani draf surat keluar eksternal tersebut dan dikembalikan kepada Tata Usaha untuk dilakukan update pada data surat keluar yang sudah disetujui. Proses surat keluar eksternal digambarkan activity diagram proses surat keluar pada gambar 4.

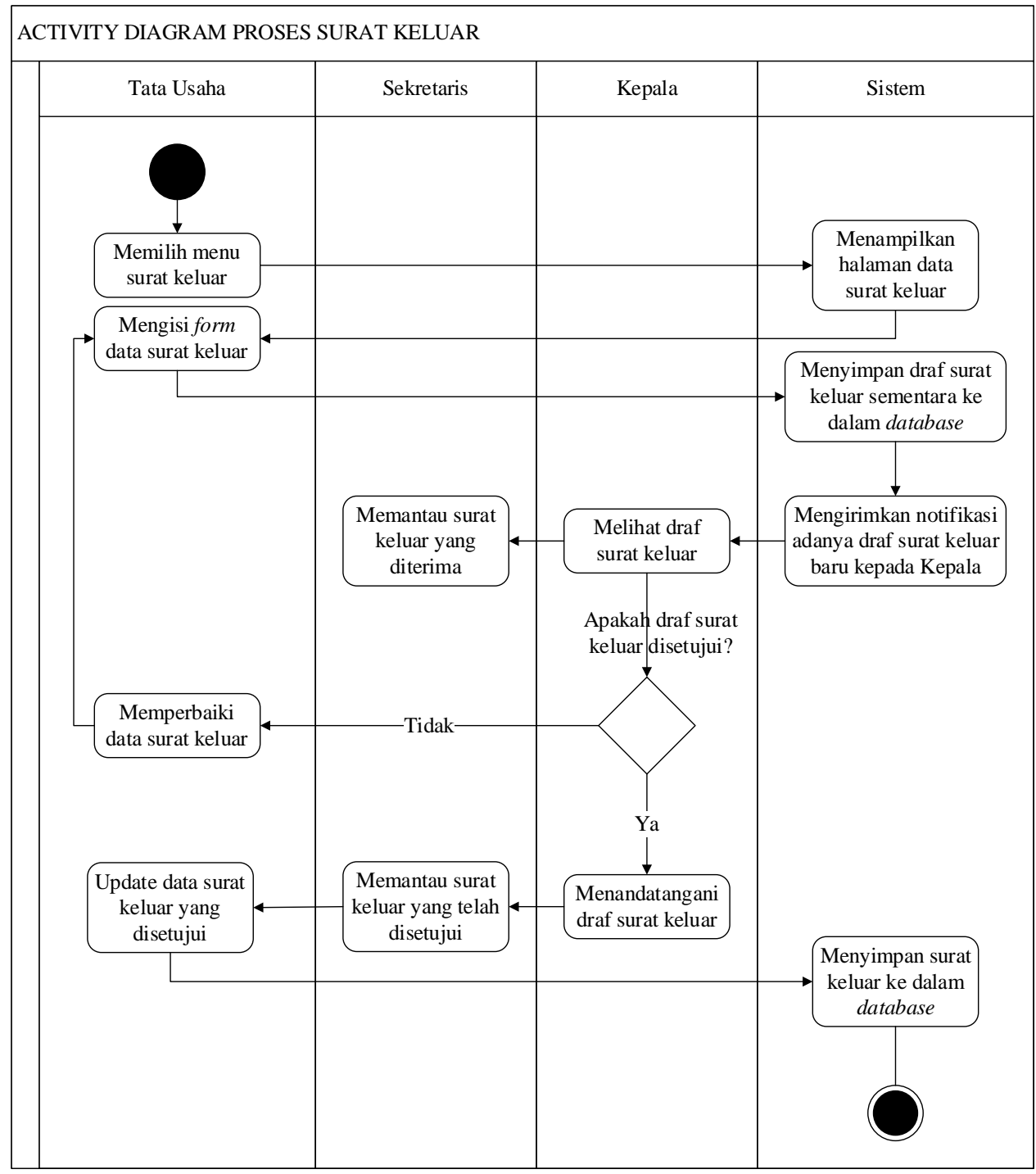

Gambar 4. Activity Diagram Proses Surat Keluar

Class Diagram mendeskripsikan susunan dari suatu sistem tertentu dengan metode pemodelan class, atribut, dan relasi satu sama lain. Class Diagram memperlihatkan dan menjelaskan suatu class, atribut, maupun objek, dan relasi antar class agar terbentuknya sebuah sistem. Pengembang membuat class diagram yang dirancang berdasarkan use case diagram yang 
telah dirancang yang memaparkan atribut dan class dan fungsi yang dijalankan. User dapat melakukan akses pada class surat masuk, surat keluar, disposisi, pegawai jika user memiliki akses untuk mengelola class tersebut. Pada class User berisikan atribut data pengguna dari aplikasi, operasi yang dilakukan pada class User adalah tambah, ubah, hapus user, proses login dan logout. Class Surat Masuk dan Surat Keluar mempunyai atribut data surat, dan operasi yang dijalankan adalah tambah, ubah, hapus surat, menampilkan data surat dan pemantauan surat yang dapat dilakukan oleh aktor Sekretaris. Pada class Disposisi memiliki atribut data disposisi surat, operasi yang dilakukan yaitu tambah dan hapus disposisi, serta pemantauan atau tracking surat yang dilakukan oleh aktor Sekretaris. Class Pegawai mempunyai atribut data pegawai UPTD SPNF SKB Salatiga, dalam class Pegawai memiliki operasi tambah, ubah, hapus data pegawai. Class Pegawai digunakan untuk keperluan pendisposisian surat yaitu pegawai yang akan dituju. Class diagram sistem informasi arsip surat dapat dilihat pada gambar 5 .
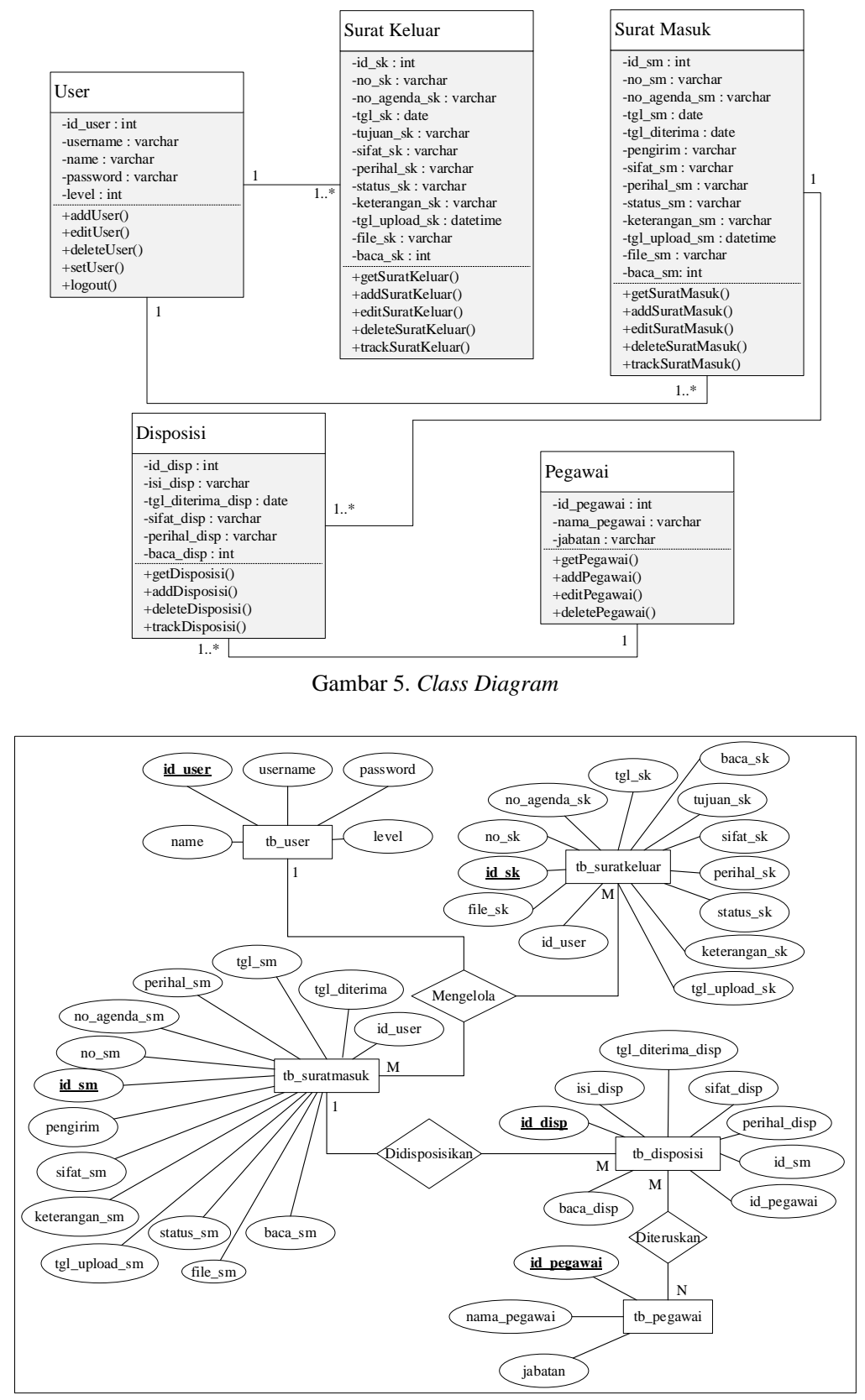

Gambar 6. Entity Relationship Diagram

Entity Relationship Diagram adalah metode pendekatan yang menjelaskan hubungan antara model. Pada relasi diagram ini menampilkan data objek (Entity) dan relasi (Relationship) yang terdapat pada Entitas selanjutnya [14]. Gambar 6 merupakan entity relationship diagram dari sistem informasi arsip surat. Tabel User dapat mengelola Tabel Surat Masuk 
dan Tabel Surat Keluar dengan relasi one to many dikarenakan user yang memiliki hak akses tersebut dapat mengelola banyak surat masuk dan surat keluar. Tabel Surat masuk dapat didisposisikan dengan banyak menggunakan relasi one to many dengan Tabel Disposisi. Relasi Tabel Disposisi dengan Tabel Pegawai menggunakan relasi many to many dikarenakan ketika satu surat masuk yang dikirim kepada banyak pegawai dalam satu disposisi surat.

\section{Construction of Prototype}

Setelah dilakukan perancangan dan mengidentifikasi gambaran umum tentang perangkat lunak yang akan dibuat, pada tahap ini pengembang membuat prototype sistem informasi arsip surat. Hasil dari prototype dijelaskan sebagai berikut:

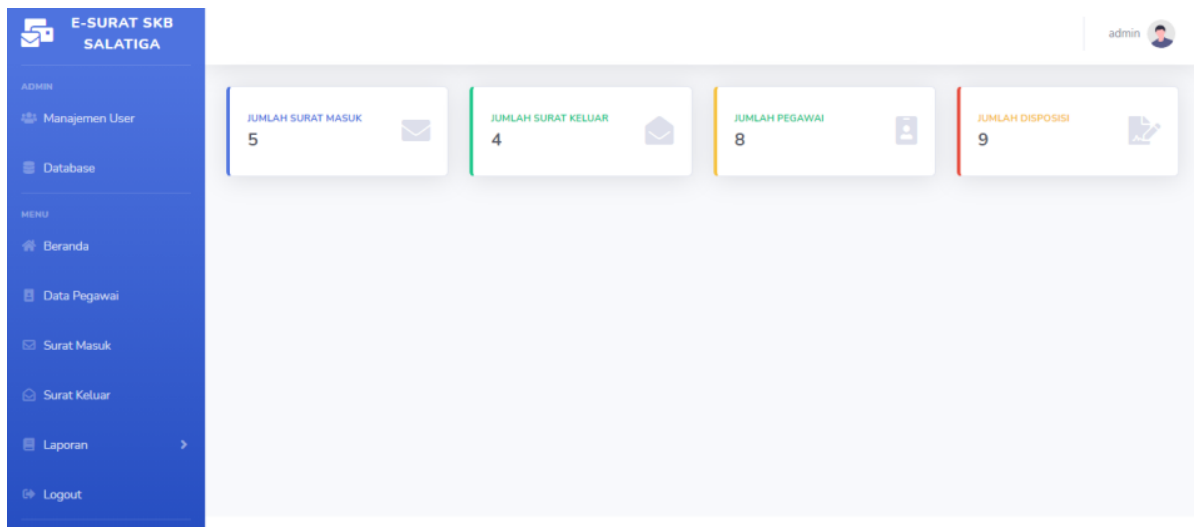

Gambar 7. Beranda

Gambar 7 merupakan hasil prototype halaman beranda. Halaman beranda berisi tentang informasi jumlah surat masuk, jumlah surat keluar, jumlah pegawai, dan jumlah disposisi yang telah diinputkan pada Sistem Informasi Arsip Surat.
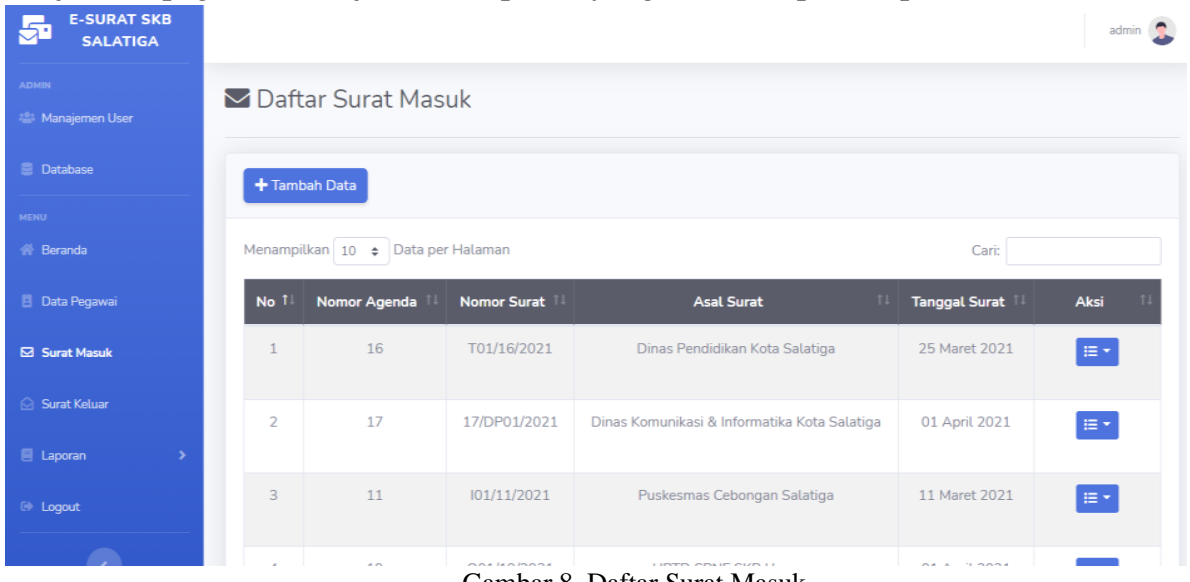

Gambar 8. Daftar Surat Masuk

Gambar 8 merupakan hasil prototype halaman surat masuk yang menampilkan daftar dari surat masuk di antaranya nomor agenda, nomor surat, asal surat, dan tanggal surat yang telah diinputkan oleh user pada Sistem Informasi Arsip Surat.
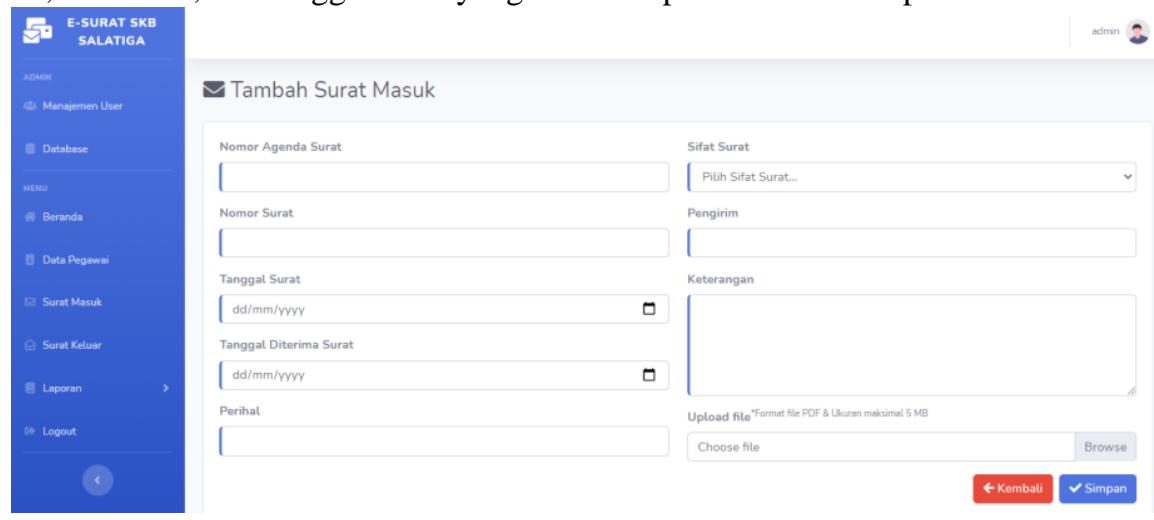

Gambar 9. Form Tambah Surat Masuk 
Gambar 9 merupakan hasil prototype halaman form tambah surat masuk untuk menambahkan data surat masuk. Form untuk menambahkan data surat masuk berisikan nomor agenda surat, nomor surat, tanggal surat, tanggal diterimanya surat, perihal, sifat surat, pengirim, keterangan jika diperlukan, dan form untuk upload berkas.

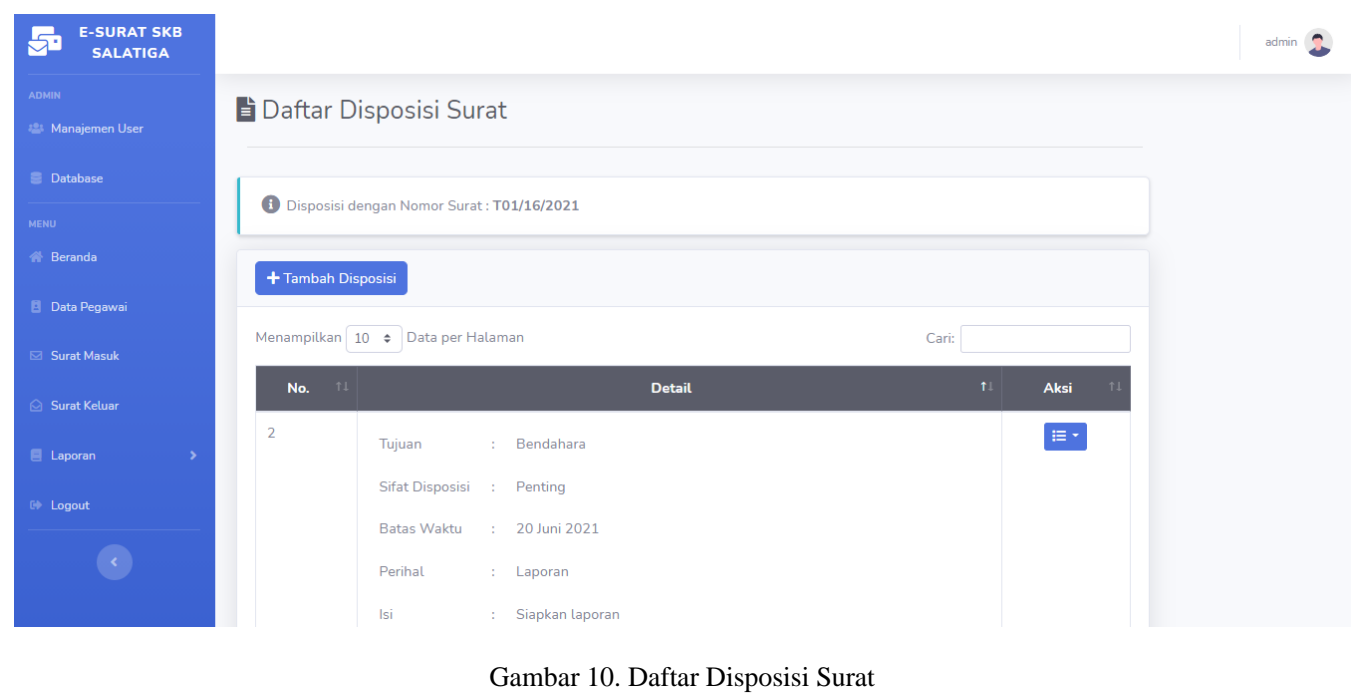

Gambar 10 merupakan hasil prototype halaman daftar disposisi surat yang menampilkan informasi pada tabel yaitu tujuan disposisi, sifat disposisi, batas waktu, perihal, isi disposisi, dan kolom aksi dengan tombol untuk melihat detail disposisi dan menghapus disposisi. Satu surat yang akan didisposisikan bisa untuk ke berbagai bagian atau pegawai.

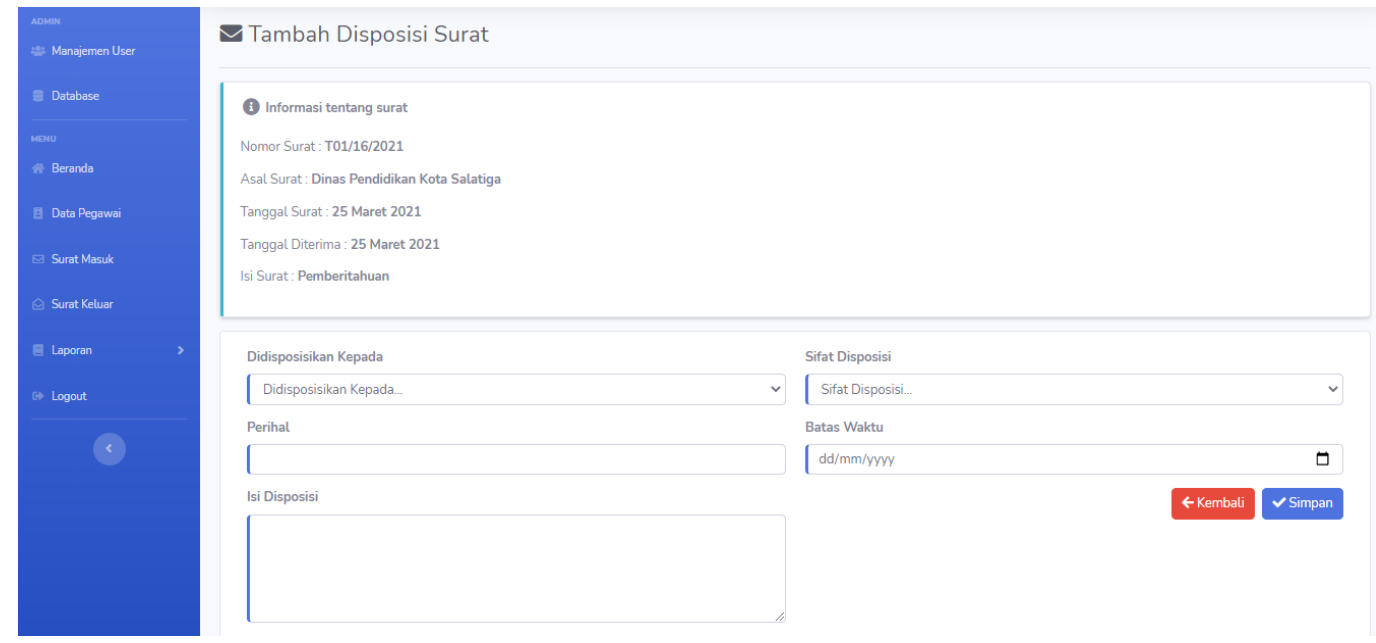

Gambar 11. Form Tambah Disposisi Surat

Gambar 11 merupakan hasil prototype halaman tambah disposisi surat yang menampilkan informasi tentang surat yang akan didisposisikan dan form untuk menambahkan disposisi surat berisikan tujuan disposisi, perihal, isi disposisi, sifat disposisi, dan batas waktu disposisi.

\section{Deployment Delivery \& Feedback}

Setelah hasil rancangan awal atau prototype dari Sistem Informasi Arsip Surat ini dibuat, dilakukan analisis terhadap aplikasi untuk mendapatkan feedback dari pengguna tentang fitur dan tampilan dari prototype aplikasi. Prototype dari Sistem Informasi Arsip Surat ini diberikan kepada calon pengguna yaitu Administrator, Sekretaris, Tata usaha, dan Kepala UPTD SPNF SKB Salatiga yang juga memberikan pendapat dan saran untuk mendapatkan feedback. Pendapat dan saran tersebut disajikan dalam Tabel 2. 
TABEL 2

TABEL FEEDBACK PENGGUNA

\begin{tabular}{llc}
\hline \multicolumn{1}{c}{ Komponen } & \multicolumn{1}{c}{ Feedback Pengguna } & Kesimpulan \\
\hline Halaman Beranda. & $\begin{array}{l}\text { Menyarankan untuk menambahkan grafik yang menampilkan } \\
\text { diagram jumlah surat masuk, jumlah surat keluar, dan statistik } \\
\text { jumlah surat masuk \& surat keluar yang masuk setiap bulan } \\
\text { dan tahun. }\end{array}$ & Perlu dievaluasi \\
\hline Halaman Surat. & $\begin{array}{l}\text { Menyarankan untuk menambahkan fitur log aktivitas dan } \\
\text { riwayat surat, dan menambahkan kolom status surat pada } \\
\text { tabel. }\end{array}$ & Perlu dievaluasi \\
\hline Halaman Tambah Surat. & $\begin{array}{l}\text { Menyarankan untuk penambahan fitur tracking surat masuk, } \\
\text { surat keluar, dan disposisi surat masuk. }\end{array}$ & Diterima \\
\hline Halaman Disposisi Surat. & Fungsi sudah berjalan sesuai dengan yang direncanakan. & Diterima \\
\hline Halaman Tambah Disposisi Surat. & Fungsi sudah berjalan dengan baik. & Diterima \\
\hline Halaman Cetak Laporan Surat. & $\begin{array}{l}\text { Fungsi cetak sudah berjalan dengan baik pada periode tanggal, } \\
\text { bulan, maupun tahun. }\end{array}$ & Diterima \\
\hline $\begin{array}{l}\text { Halaman Cetak Lembar } \\
\text { Disposisi. }\end{array}$ & \begin{tabular}{l} 
Fitur cetak lembar disposisi sudah berjalan dengan baik. \\
\hline
\end{tabular}
\end{tabular}

\section{HASIL DAN PEMBAHASAN}

Implementasi sistem dibutuhkan untuk memberikan petunjuk penggunaan sistem kepada pengguna, pengguna dari sistem ini terdiri atas 4 user yaitu Administrator, Sekretaris, Tata Usaha, dan Kepala UPTD SPNF SKB Salatiga, sehingga pengguna sistem ini dapat menilai fungsi-fungsi yang terdapat pada sistem dan menanggapi apakah sistem perlu disempurnakan agar kebutuhan pengguna sistem dapat terpenuhi. Penerapan sistem informasi arsip surat berbasis website pada UPTD SPNF SKB Salatiga dibangun dengan menggunakan bahasa pemrograman PHP memanfaatkan salah satu framework_PHP yaitu Codeigniter, editor kode yang digunakan adalah Visual Studio Code, MySQL sebagai basis data, HTML, CSS, dan Javascript sebagai tampilan luar dari aplikasi yang dirancang ini.
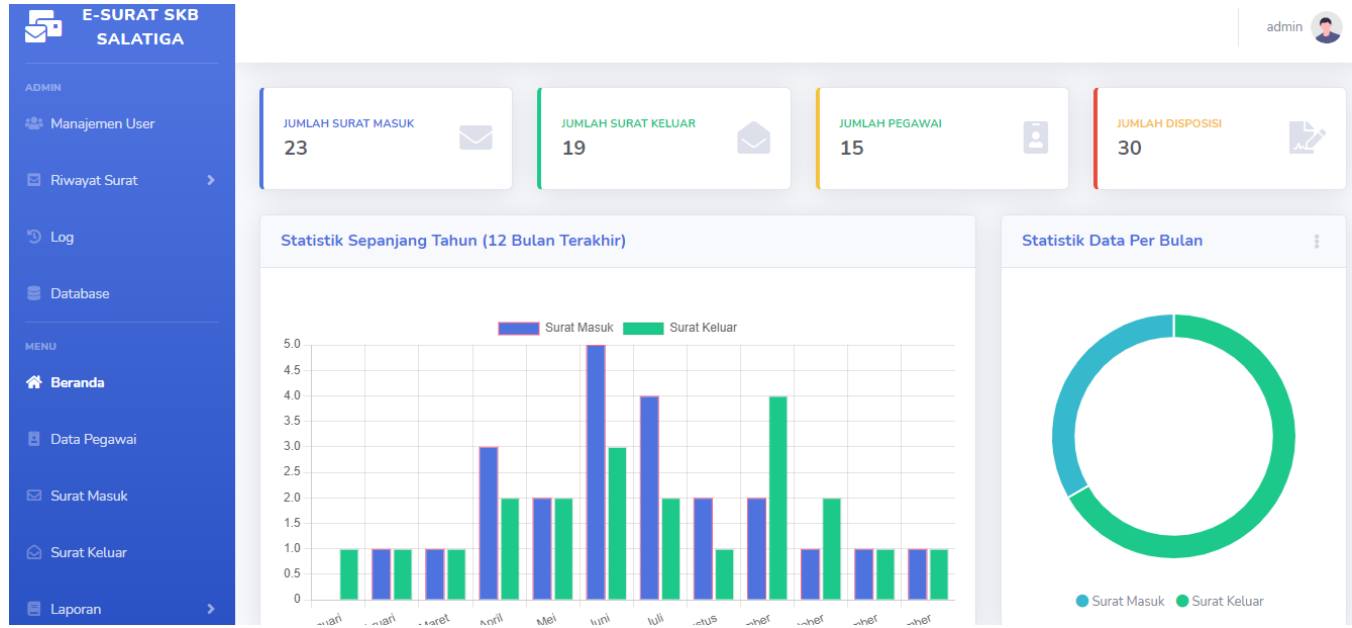

Gambar 12. Halaman Beranda Sesudah Dievaluasi 
Prototype halaman beranda dinilai kurang informatif, oleh karena itu perlu ditambahkan grafik batang dan grafik lingkaran yang menampilkan statistik data surat yang didata secara bulanan dan tahunan dengan memanfaatkan library ChartJS mengambil fitur bar chart untuk menampilkan statistik sepanjang tahun dan pie chart untuk menampilkan statistik data per bulan yang berisikan data surat masuk dan surat keluar. Gambar 12 merupakan tampilan antarmuka hasil dari perubahan yang didapat dari saran pengguna dengan menampilkan jumlah surat masuk, jumlah surat keluar, jumlah bagian atau pegawai, grafik batang untuk menampilkan statistik data surat tahunan, dan grafik lingkaran untuk menampilkan statistik data surat per bulan.

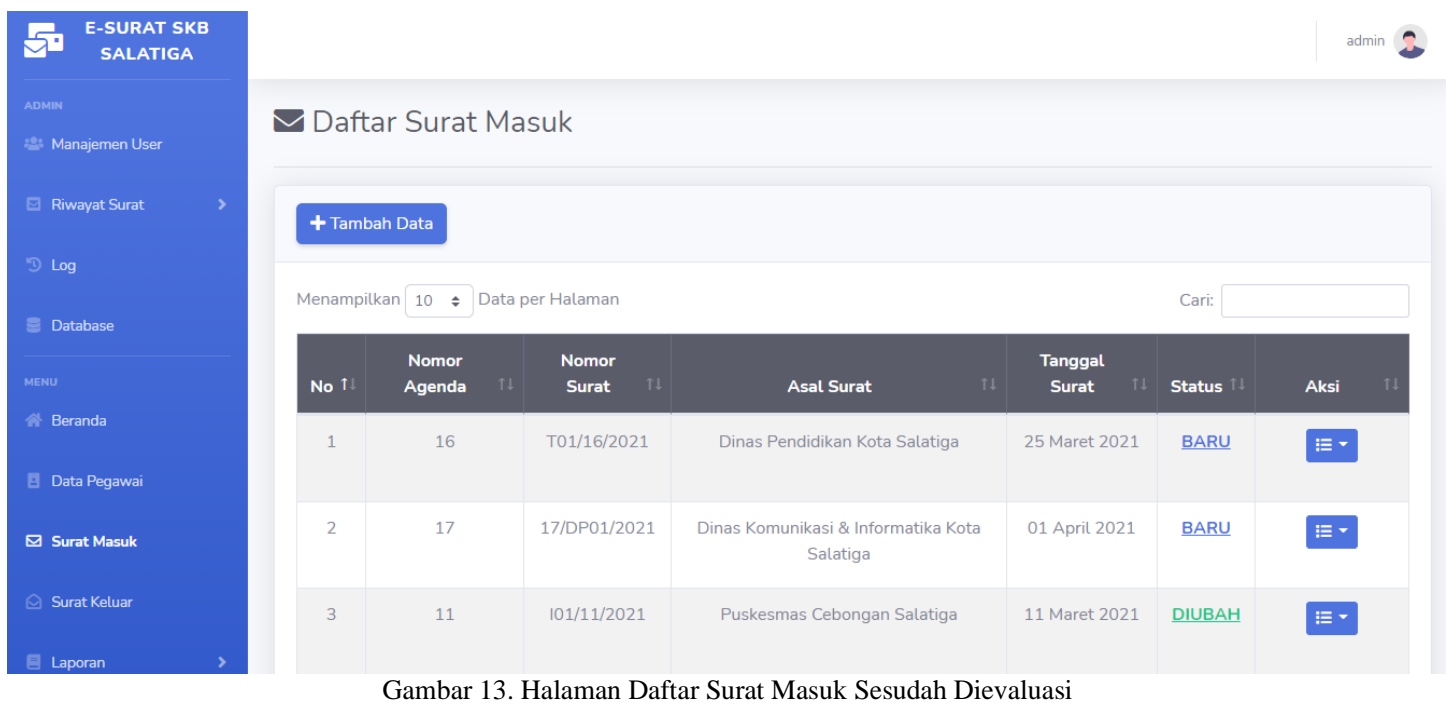

Gambar 13 merupakan hasil dari halaman surat masuk yang dibuat berdasarkan feedback dari pengguna. Prototype sebelumnya dievaluasi dengan menambahkan kolom status surat pada tabel yang berisi "Baru" dan "Diubah" sehingga dapat terlihat surat yang baru masuk dan yang sudah pernah diubah.
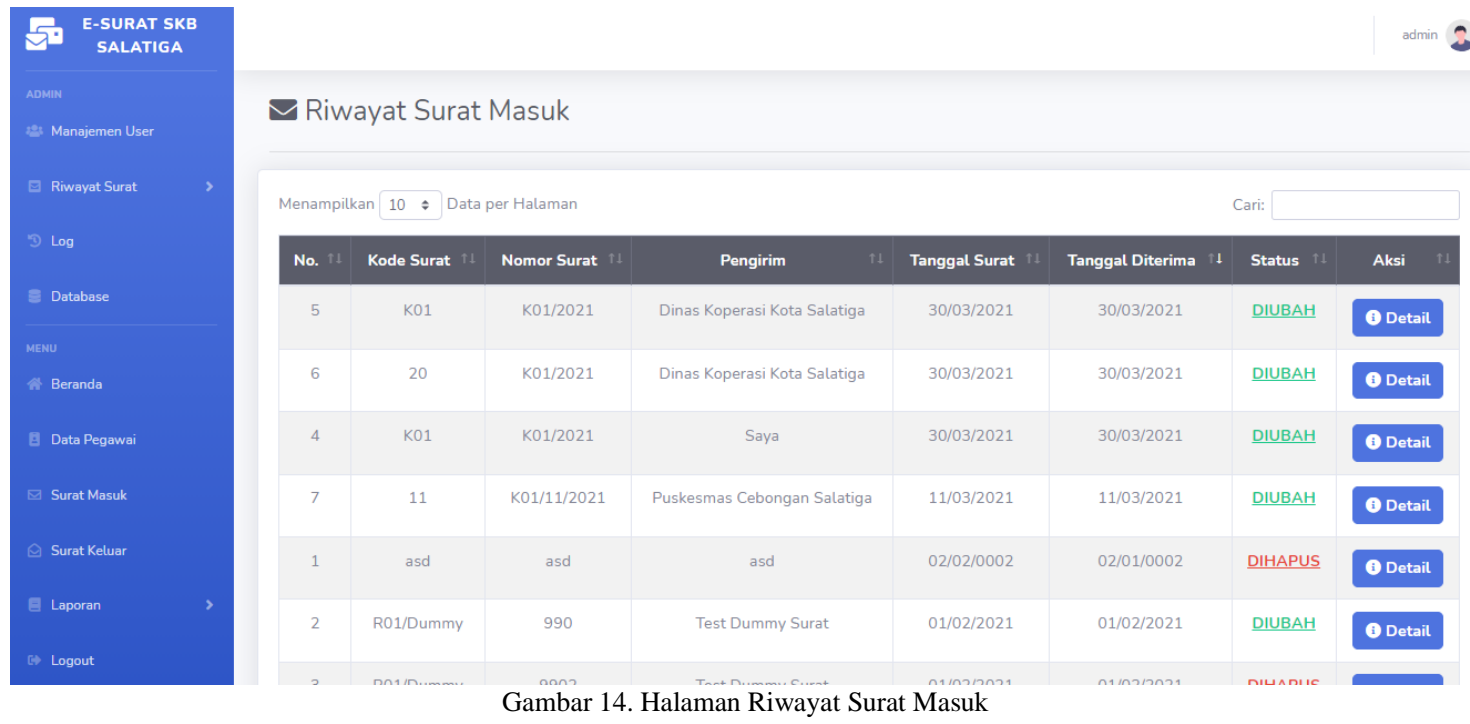

Gambar 14 merupakan tampilan hasil dari feedback pengguna yang menyarankan untuk menambahkan fitur history atau riwayat surat pada aplikasi. Ketika suatu data surat diubah maka riwayat data surat yang belum diubah akan disimpan pada halaman riwayat surat masuk dengan diberikan status "Diubah" dan jika ada data surat yang dihapus maka juga akan tersimpan pada halaman ini dengan diberikan status "Dihapus". Halaman ini dibuat berdasarkan feedback dari pengguna yang menyarankan adanya status surat pada halaman surat masuk sehingga ketika ada suatu data surat yang diedit maupun dihapus akan tersimpan pada halaman ini. 

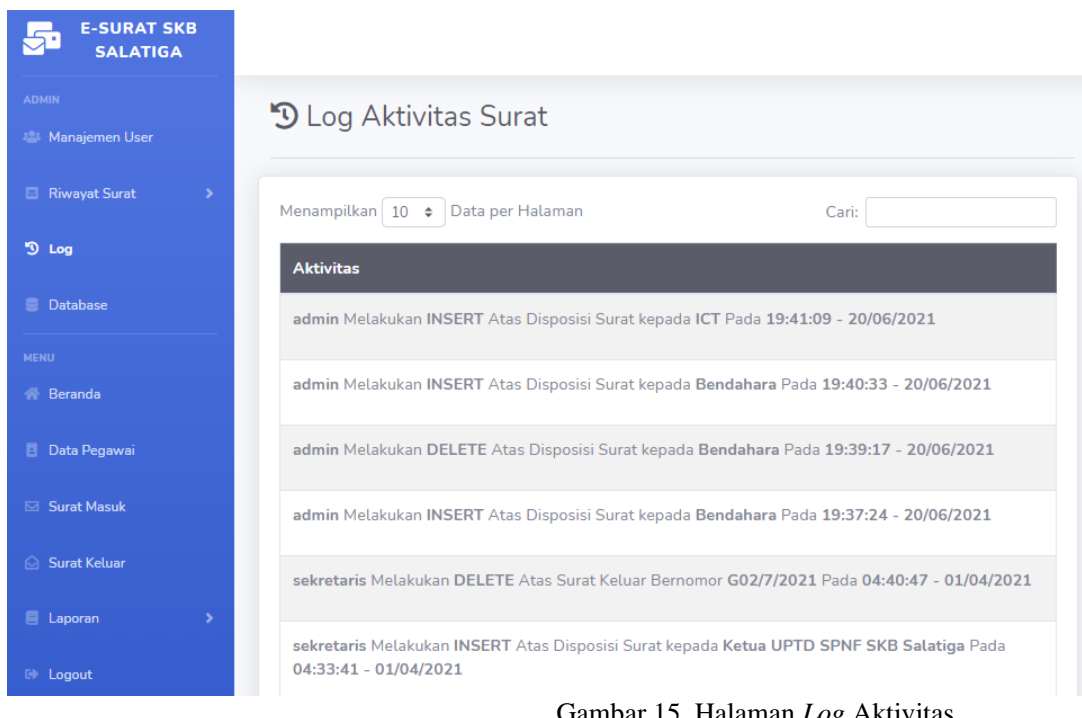

Gambar 15. Halaman Log Aktivitas

Gambar 15 merupakan halaman log aktivitas hasil dari feedback pengguna yang memberi saran untuk penambahan fitur log aktivitas. Informasi yang termuat dalam halaman log aktivitas adalah kegiatan apa saja yang dilakukan oleh user. Isi tabel log aktivitas terdiri dari aktivitas yang dilakukan yaitu tambah, ubah, atau delete, user yang terlibat, aktivitas yang dilakukan pada surat tertentu, dan tanggal \& waktu terjadinya aktivitas tersebut. Log aktivitas dibuat dengan tujuan untuk memantau kegiatan yang dilakukan oleh pengguna pada saat menggunakan Sistem Informasi Arsip Surat ini.

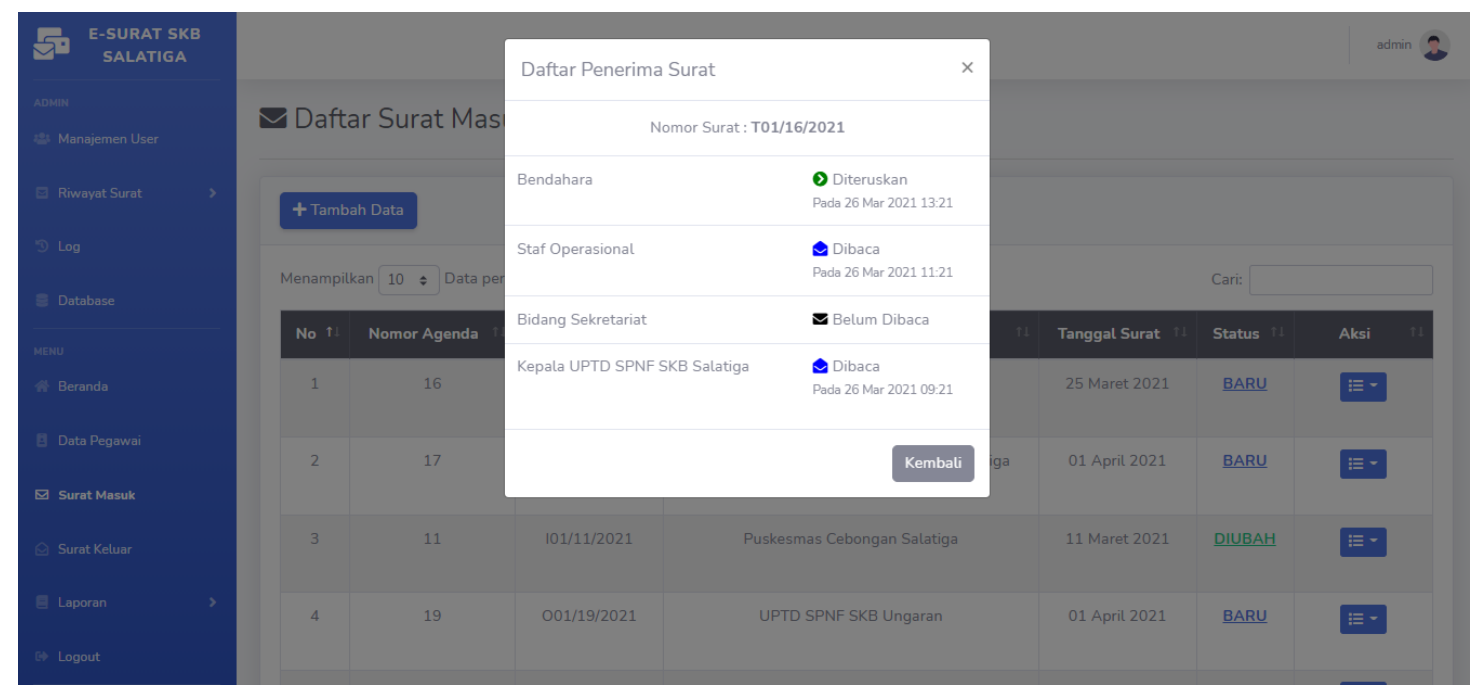

Gambar 16. Tracking Surat

Gambar 16 merupakan halaman daftar surat masuk yang didalamnya ada fitur tracking atau pemantauan surat masuk. Isi dari tracking surat masuk adalah nomor surat, daftar penerima surat masuk dengan keterangan penerima surat masuk, aktivitas yang dilakukan penerima, dan waktu aktivitas itu dilakukan. Fungsi tracking surat ini juga terdapat pada surat keluar dan disposisi surat. Fitur tracking disposisi surat dibutuhkan untuk memudahkan pengguna dalam memonitor disposisi surat, surat masuk, maupun surat keluar.

Hasil dari penelitian ini adalah sistem pengarsipan surat berbasis website yang mempunyai berbagai macam fungsi seperti pendataan surat masuk, detail surat masuk, pendataan surat keluar, detail surat keluar, pendisposisian surat masuk, cetak laporan surat masuk, cetak laporan surat keluar, cetak lembar disposisi, tracking surat masuk, tracking surat keluar, dan tracking disposisi surat. Sistem informasi arsip surat diuji menggunakan black box testing bertujuan untuk melihat fungsi dari sistem yang dirancang dapat berfungsi sesuai dengan kode program yang dibuat tanpa melihat kode program 
berisikan fungsi yang digunakan. Tabel 3 adalah pengujian black box pada semua fungsi yang terdapat pada sistem informasi arsip surat. Hasil pengujian yaitu semua fungsi dapat berjalan sesuai dengan yang realisasi yang diharapkan dengan berbagai skenario pengujian yang diuji.

TABEL 3

BLACK BOX TESTING

\begin{tabular}{|c|c|c|c|}
\hline $\begin{array}{l}\text { Skenario } \\
\text { Pengujian }\end{array}$ & Realisasi yang diharapkan & Hasil Pengujian & Kesimpulan \\
\hline Klik menu beranda & $\begin{array}{l}\text { Memunculkan tampilan halaman } \\
\text { beranda }\end{array}$ & Halaman beranda berhasil dimuat & Berhasil \\
\hline $\begin{array}{l}\text { Melakukan login pada } \\
\text { aplikasi. }\end{array}$ & Masuk ke dalam aplikasi. & $\begin{array}{l}\text { Fungsi login dapat berjalan sesuai yang } \\
\text { diharapkan. }\end{array}$ & Berhasil \\
\hline $\begin{array}{l}\text { Melakukan logout pada } \\
\text { aplikasi. }\end{array}$ & Keluar dari aplikasi. & $\begin{array}{l}\text { Fungsi logout berfungsi sesuai yang } \\
\text { diharapkan. }\end{array}$ & Berhasil \\
\hline $\begin{array}{l}\text { Menambahkan disposisi } \\
\text { surat masuk. }\end{array}$ & $\begin{array}{l}\text { Data disposisi ditambahkan } \\
\text { kedalam aplikasi }\end{array}$ & Data disposisi berhasil ditambahkan. & Berhasil \\
\hline $\begin{array}{l}\text { Menambahkan data surat } \\
\text { masuk. }\end{array}$ & $\begin{array}{l}\text { Data surat masuk tersimpan ke } \\
\text { dalam aplikasi. }\end{array}$ & Data surat masuk berhasil disimpan. & Berhasil \\
\hline $\begin{array}{l}\text { Menambahkan data surat } \\
\text { keluar. }\end{array}$ & $\begin{array}{l}\text { Data surat keluar tersimpan ke } \\
\text { dalam aplikasi. }\end{array}$ & Data surat keluar berhasil disimpan. & Berhasil \\
\hline Melihat detail surat masuk. & Menampilkan detail surat masuk. & Detail surat masuk berhasil dimuat. & Berhasil \\
\hline Melihat detail surat keluar. & Menampilkan detail surat keluar. & Detail surat keluar berhasil dimuat. & Berhasil \\
\hline $\begin{array}{l}\text { Melihat detail disposisi } \\
\text { surat. }\end{array}$ & $\begin{array}{l}\text { Menampilkan detail disposisi } \\
\text { surat. }\end{array}$ & Detail surat disposisi berhasil dimuat. & Berhasil \\
\hline $\begin{array}{l}\text { Cetak laporan surat masuk } \\
\text { atau surat keluar } \\
\text { berdasarkan periode. }\end{array}$ & $\begin{array}{l}\text { Memuat hasil laporan sesuai } \\
\text { periode yang dipilih. }\end{array}$ & Laporan berhasil dicetak. & Berhasil \\
\hline Cetak lembar disposisi. & Memuat hasil lembar disposisi. & Lembar disposisi berhasil dicetak. & Berhasil \\
\hline Tracking surat masuk. & $\begin{array}{l}\text { Memuat informasi tentang } \\
\text { penerima surat masuk dan } \\
\text { aktivitas yang sudah dilakukan. }\end{array}$ & $\begin{array}{l}\text { Tampilan daftar penerima surat masuk } \\
\text { beserta informasi terkait berhasil } \\
\text { dimuat. }\end{array}$ & Berhasil \\
\hline Tracking disposisi surat. & $\begin{array}{l}\text { Memuat informasi tentang } \\
\text { penerima disposisi surat. }\end{array}$ & $\begin{array}{l}\text { Tampilan daftar penerima disposisi } \\
\text { surat berhasil dimuat. }\end{array}$ & Berhasil \\
\hline
\end{tabular}

Berdasarkan hasil black box testing yang dilakukan oleh pengguna pada Tabel 3 dapat disimpulkan telah dilakukan perbaikan dan penambahan fitur pada sistem informasi arsip surat ini. Penambahan statistik data surat masuk dan data surat keluar yang masuk ke dalam sistem informasi arsip surat bulanan dan tahunan sehingga informasi disampaikan dengan lebih jelas. Penambahan fitur $\log$ aktivitas dan riwayat surat yang bertujuan untuk merekam aktivitas yang dilakukan pengguna dan menyimpan berkas yang sudah dihapus maupun diubah sehingga jika dibutuhkan bisa untuk digunakan kembali. Penambahan fitur tracking surat dan disposisi surat untuk memantau aktivitas dari surat, siapa yang menerima surat, siapa saja yang mendapat disposisi surat. Selain itu, fitur lainnya sudah berjalan dengan baik dan sesuai dengan yang direncanakan sehingga sistem informasi arsip surat UPTD SPNF SKB Salatiga siap untuk digunakan. 


\section{SIMPULAN}

Dari hasil prototype awal aplikasi yang diberikan kepada pengguna aplikasi yaitu pegawai UPTD SPNF SKB Salatiga, feedback berupa saran dan masukan yang diberikan para pegawai menghasilkan perbaikan aplikasi di antaranya pembaruan tampilan beranda aplikasi, penambahan status surat pada halaman surat, penambahan fitur log aktivitas dan riwayat surat, dan penambahan fungsi tracking surat. Keikutsertaan para pegawai UPTD SPNF SKB Salatiga dalam pengembangan sistem informasi arsip surat ini adalah dengan memberikan feedback berupa saran dan masukan, sehingga hasil dari aplikasi akan semakin mudah disesuaikan dengan kebutuhan dari UPTD SPNF SKB Salatiga. Penggunaan metode prototype pada penelitian ini dapat mempermudah pengembang dalam merancang sistem dengan feedback dari pegawai sehingga dapat menghasilkan sistem yang optimal dan mudah disesuaikan dengan kebutuhan dan mengatasi permasalahan terkait pengarsipan surat pada UPTD SPNF SKB Salatiga agar terciptanya efisiensi dalam pekerjaan. Kesulitan yang dihadapi pada penelitian ini yaitu sistem ini terbatas pada website saja, pengembangan sistem berbasis mobile atau android sulit untuk dilakukan dalam jangka waktu yang singkat, oleh karena itu kedepannya perlu untuk dikembangkan kembali agar sistem ini dapat digunakan pada website maupun mobile, sistem ini hanya bisa berjalan pada komputer dan belum bisa melalui smartphone karena sistem ini masih berjalan pada lab komputer UPTD SPNF SKB Salatiga, untuk keamanan kemungkinan masih ditemukan celah untuk disalahgunakan oleh pihak yang tidak bertanggung jawab, oleh karena itu untuk kedepannya perlu dikembangkan lagi agar terciptanya sistem yang aman dan terbebas dari serangan hacker. Sistem Informasi Arsip Surat dirancang berbasis website yang diharapkan memudahkan pegawai dalam mengakses sistem karena mudahnya akses website dan ringan untuk digunakan. Sistem Informasi Arsip Surat ini dirancang dengan basis website yang ringan dan mudah digunakan dengan harapan para pegawai mudah untuk mengoperasikannya dan aplikasi ini dibuat dengan tujuan agar proses pengarsipan surat dapat berjalan lebih efektif dan efisien dan membantu petugas dalam mempersingkat waktu proses pengelolaan arsip surat.

\section{UCAPAN TERIMA KASIH}

Ucapan terimakasih kepada UPTD SPNF SKB Salatiga yang telah membantu dan bersedia untuk dijadikan tempat untuk penelitian ini. Terima kasih kepada pembimbing, teman - teman yang sudah banyak membantu dalam pembuatan penelitian ini.

\section{DAFTAR PUSTAKA}

[1] R. Ishak, Setiaji, A. Fajar, and S. Mahmud, "Rancang Bangun Sistem Informasi Surat Masuk Dan Surat Keluar Berbasis Web Menggunakan Metode Waterfall,” J. Indones. Sos. Teknol., vol. 1, no. 3, pp. 198-209, 2020.

[2] A. Suryadi, "Rancang Bangun Sistem Pengelolaan Arsip Surat Berbasis Web Menggunakan Metode Waterfall (Studi Kasus : Kantor Desa Karangrau Banyumas)," J. Khatulistiwa Inform., vol. 7, no. 1, pp. 13-21, 2019, doi: 10.31294/jki.v7i1.36.

[3] I. Prabowo and A. Kurniawan, "Rancang Bangun Aplikasi Pengarsipan Surat Dan Disposisi (Apsd) Berbasis Website Menggunakan Framework Laravel (Studi Kasus: Kantor Dinas Pertanian Dan Ketahanan Pangan Kota Madiun)," J. Manaj. Inform., vol. 11, no. 1, 2020.

[4] H. Maulana, K. Kasmawi, and D. Enda, "Buku Penghubung Berbasis Android Menggunakan Metode Prototyping," J. Tek. Inform. dan Sist. Inf., vol. 6, no. 3, pp. 521-530, 2020, doi: 10.28932/jutisi.v6i3.2993.

[5] S. Hidayat and U. Jumiatun, "Prosedur Pengelolaan Surat Untuk Memperlancar Proses Penyampaian Informasi Pada Kantor Kecamatan Pamulang," Sekretari, vol. 3, no. 1, p. 33, 2017, doi: 10.32493/skr.v3i1.637.

[6] M. Fathurrahman, "Pentingnya Arsip Sebagai Sumber Informasi," JIPI (Jurnal Ilmu Perpust. dan Informasi), vol. 3, no. 2, pp. 215-225, 2018.

[7] A. Kadir, "Pengenalan sistem informasi edisi revisi. Yogyakarta: Andi, 2.No Title," Ed. Revisi, no. August, 2014, doi: 10.13140/2.1.2637.6328.

[8] M. C. Utami, Y. T. Hutomo, P. Sistem, I. Sains, U. Islam, and N. Syarif, "Penerapan Waterfall Dalam Analisis Dan Perancangan Sistem Informasi Manajemen Dokumen Surat Menyurat Pada Bank BJB Kantor Cabang BSD Tangerang,” J. Sains, Teknol. dan Ind., vol. 12, no. 1, pp. $129-135,2014$.

[9] A. Firman, H. F. Wowor, and X. Najoan, "Sistem Informasi Perpustakaan Online Berbasis Web," E-Journal Tek. Elektro dan Komput., vol. 5, no. 2, pp. 29-36, 2016.

[10] E. R. Susanto and F. Ramadhan, "Rancang Bangun Aplikasi Berbasis Web Perizinan Praktik Tenaga Kesehatan Menggunakan Framework Codeigniter Pada Dinas Kesehatan Kota Metro," J. Tekno Kompak, vol. 11, no. 2, p. 55, 2017, doi: 10.33365/jtk.v11i2.173.

[11] H. Yuliansyah, "Perancangan Replikasi Basis Data MySQL Dengan Mekanisme Pengamanan Menggunakan SSL Encryption," J. Inform., vol. 8, no. 1 , pp. 826-836, 2014

[12] Marisa and Widiyawati, "Rancang Bangun Aplikasi Sistem E-Learning Dengan Metode Prototype Pada Smk Widya Nusantara," J. Gerbang, vol. 9, no. 1, pp. 69-74, 2019.

[13] Pressman R.S., "Rekayasa Perangkat Lunak: Pendekatan Praktis,” Edisi. 7, 2012.

[14] E. W. Fridayanthie and T. Mahdiati, "Rancang Bangun Sistem Informasi Permintaan Atk Berbasis Intranet (Studi Kasus: Kejaksaan Negeri Rangkasbitung)," J. Khatulistiwa Inform., vol. IV, no. 2, pp. 126-138, 2016, [Online]. Available: www.iranesrd.com. 